\title{
APPLICATION OF UNMANNED AERIAL VEHICLES FOR REMOTE ESTIMATION OF PASTURE FERTILITY WHILE GROWING DZHALGINSKY MERINO SHEEP
}

\author{
Vladimir Trukhachev, Sergei Oliinyk, Tatyana Lesnyak, Nikolay Zlyidnev \\ Stavropol State Agrarian University, Russia \\ rector@stgau.ru,soliynik60@gmail.com, tatastav026@gmail.com,nz-korlenec@yandex.ru
}

\begin{abstract}
Agricultural exploration of an area is one of the effective ways to use aerospace monitoring. The range of issues that can be solved with the images from satellite photographs and technological equipment of unmanned aerial vehicles includes the task of receiving some information about the composition and condition of crops, potential yields, diseases and damage to crops by pests, the problem of land inventory, biomass estimation and study of the dynamics of agricultural land use. In order totake a remote assessment of pasture fertility, an unmanned aerial vehicle equipped with a special camera for calculating the NDVI (Normalized Difference Vegetation Index) was used. Researches of domestic and foreign authors show that maximum absorption of solar radiation by chlorophyll of higher vascular plants is in the red region of the spectrum (0.6$0.7 \mu \mathrm{m})$, and the region of maximum reflection of cellular leaf structures is in the infrared region $(0.7-1.0 \mu \mathrm{m})$. It enables the NDVI index to be used as a simple quantitative indicator of the amount of photosynthetically active biomass. The results of monitoring the NDVI index on pastures of the Stavropol Territory of the Russian Federation were compared with the results of the analysis of pasture grass for carotene content. The correlation index was 0.98. On the basis of the obtained data, the regression equations were calculated. They enable topredict the dynamics of changes in the nutritional value of pasture plots and determine the load of livestock of Dzhalginskiy Merino sheep.
\end{abstract}

Key words: remote monitoring, unmanned aerial vehicles, pasture, sheep, Dzhalginskiy Merino breed.

\section{Introduction}

The use of remote monitoring for studying agricultural areas is becoming more common in recent times. The advantages of materials obtained from remote aerospace surveys are the uniformity and comparability of the data obtained for vast areas, greater visibility, modernity and permanence. They are decisive factors while choosing methods forsolving the above-named problems. The disadvantages are not enough high resolution of satellite services and presence of atmospheric noise in the form of clouds. Sometimes they can make it difficult to interpret the results objectively [1;2].

It is more efficient to use services derived from the use of unmanned aerial vehicles for operational management of production processes in grazing. At the same time, the issues such as the task of quick receiving of information on the composition and condition of crops, potential yields, diseases and damage to crops by pests, land inventory, biomass estimation, and research of the dynamics of agricultural land use are available for solving. Decision making is based on the use of photographic and video materials from the technological equipment of unmanned aerial vehicles $[3 ; 4]$.

One of the directions of remote monitoring is the assessment of the extent of accumulation of plant biomass on pastures. It is based on the determination of the vegetation index that depends on spectral measurements in the red and infrared regions of the spectrum. At the same time, an unmanned aerial vehicle equipped with the special camera for calculating the NDVI index (Normalized Difference Vegetation Index) can be used to conduct a remote assessment of pasture fertility [5;6].

Studies by domestic and foreign authors show that the maximum absorption of solar radiation by chlorophyll of higher vascular plants is in the red region of the spectrum $(0.6-0.7 \mu \mathrm{m})$, and the region of maximum reflection of leaf cell structures is in the infrared region $(0.7-1.0 \mu \mathrm{m})[7 ; 8]$. The NDVI is a simple quantitative measure of the amount of photosynthetically active biomass (usually called the vegetative index). In the wavelength range of 600-700 $\mathrm{nm}$ (visible red light), chlorophyll has high peak absorption. In the area of NIR (Near InfraRed - near infrared (IR) range), vegetation has a high reflection coefficient. The following equation can be used for calculating the NDVI (1):

$$
N D V I=\frac{N I R-R e d(B l u e)}{N I R+R e d(B l u e)},
$$

where $N I R$ - near infrared reflection;

Red (Blue) - reflection in the red (blue) region of the spectrum. 
Currently $[9 ; 10]$ scientists have begun to use near-infrared and red light data for assessing the productivity of vegetation. Thus, NDVI can be calculated on the basis of any high, medium or low resolution images that have spectral channels in the red $(0.55-0.75 \mu \mathrm{m})$ and infrared range $(0.75$ $1.0 \mu \mathrm{m})$.

The NDVI enables to compare data on the state of biomass of pasture plots from different geographic areas produced at different times of the day or year, becausethe NDVI is the normalized difference between red and near infrared light [4].

Grazing is one of the most common types of agricultural activities in the steppe regions of the southern Russia. At the same time, sheep grazing is the most important segment among other branches of animal farming. So, the number of sheep in the Stavropol Territory is about 2.2 million heads. It is almost 50 times as much as the number of specialized beef cattle [11].

Sheep growing is based on the use of traditional technologies. The lack of them is the lack of operational information on the state of plant biomass in existing pasture areas because the size of pastures can reach several thousand hectares located at a distance of several tens of kilometers from the sheep farms. The introduction of remote monitoring of the state of plant biomass of pasture plots is one of the most important ways to improve the efficiency of the livestock industry as a whole. It will enable to develop rural areas and increase the investment and social attractiveness of the industry [12].

\section{Materials and research methods}

While conducting aerial photography of the area with the further construction of a detailed digital map of the area and pasture location, the modified Canon EOS 650D camera with the red Wratten 25A filter has been used. It has enabled to record two independent image channels in one shot - visible red $(600-700 \mathrm{~nm})$ or blue and near IR ranges $(700-950 \mathrm{~nm})$. The NDVI has been calculated as the ratio of the difference between the brightness of pixels in the IR and red (blue) channels to their sum $[13 ; 14]$.The software "AgisoftMetashape" has been used for analyzing the images received with UAVs, flight path, overlap and the area covered. It enables to measure the distance and calculate the surface area and volume.

Flying around and photographing pastures have been carried out according to the "sweeping" flight pattern and presented in Figure 1.

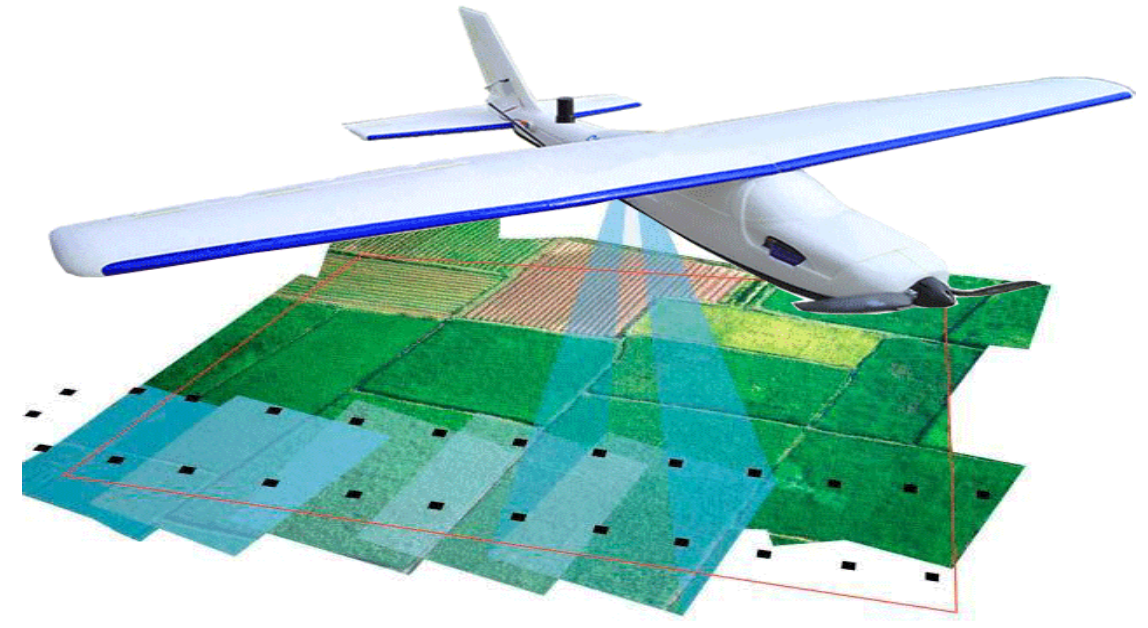

Fig. 1. Flying around and photographing pastures according to "sweeping" flight

The remote data according to the algorithms described in the document have been transformed into the NDVI surface. The surface has been used to estimate the development of pasture plant biomass. Pasture feed for research has been selected during the main growing season of plants (JuneJuly) and researchedwith standard and generally accepted methods. The chemical composition of feed (crude protein, crude fiber, crude fat, crude ash, calcium, phosphorus, amino acid composition) and moisture have been determined by the equipment of the firms INGOS (Czech Republic), FIBRETHERM (Germany), VELP SCIENTIFICA (Italy) in the Laboratory of the Scientific and 
Technical Center "Feed and metabolism" (accreditation certificate No. ROSS RU.0001.21PU12 from 28.10.2014).

Groups of animals for the research have been formed on the principle of couples-analogues from the young fat stock of Dzhalginskiy Merino sheep. The number of young sheep for fattening in each group was 100 animals. The animals were 6 months old. The control period of growing the experimental animals was 60 days.

In our studies the groups of sheep have grazed on pastures, the botanical composition of which consists of legume-cereal plants (25:75 \%): Onobrychis, Medicago, Festucapratensis, Loliumperenne. The determination of the live weight of experimental young animals has been realized by the standard zootechnic method by weighing. The pasture ecosystems have been studied using the AC-32-10 unmanned aerial vehicle and the DJI s900 hexacopter, the Canon M10 camera and the vegetation index calculation software (NDVI).

\section{Research results and discussion}

Grassdominates inthe botanical composition of grazing land. It make s80-85 \% of the total mass. The chemical composition of herbs by seasons of the year is presented in Table 1.

Table 1

Chemical composition of natural pasture grasses( $100 \mathrm{~g}$ of absolutely dry matter), \%

\begin{tabular}{|c|c|c|c|c|c|c|c|c|c|c|c|}
\hline \multirow[b]{2}{*}{$\begin{array}{c}\text { Season of } \\
\text { year }\end{array}$} & \multirow[b]{2}{*}{ 葛 } & \multirow[b]{2}{*}{ 馬 } & \multirow[b]{2}{*}{ 离 } & \multirow{2}{*}{ 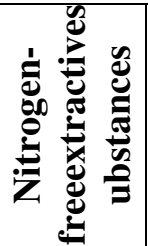 } & \multirow[b]{2}{*}{$\frac{2}{4}$} & \multirow[b]{2}{*}{ 疍 } & \multirow[b]{2}{*}{ 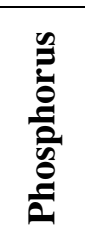 } & \multirow[b]{2}{*}{$\frac{\Xi}{\bar{\Xi}}$} & \multicolumn{3}{|c|}{ Sugars } \\
\hline & & & & & & & & & 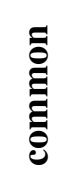 & ڤ્犬 & $:=$ \\
\hline Spring & 12.2 & 3.0 & 30.4 & 44.9 & 9.5 & 0.60 & 0.27 & 0.25 & 4.9 & 2.0 & 2.9 \\
\hline Summer & 10.5 & 3.4 & 29.62 & 47.98 & 8.5 & 0.69 & 0.31 & 0.30 & 5.0 & 2.1 & 2.9 \\
\hline Autumn & 7.3 & 2.75 & 31.57 & 48.58 & 9.8 & 0.99 & 0.15 & 0.23 & 3.4 & 1.2 & 2.2 \\
\hline Winter & 6.2 & 2.10 & 33.4 & 48.07 & 10.23 & 0.81 & 0.19 & 0.15 & 2.5 & 1.1 & 1.4 \\
\hline
\end{tabular}

The maximum content of protein and fat in pasture feed is observed in spring and summer seasons -12.2 and $10.5 \%, 3.0$ and $3.4 \%$, respectively. In winter and autumn herbage the amount of protein is nothigher than 7.3, the amount of fat is not higher than 2.75. The fiber content from summer-spring to autumn-winter periods increases from 29.62 to 33.4. In all seasons, there is a deficiency of phosphorus $(0.15-0.31 \%)$ with the excess amount of calcium $(0.60-0.99 \%)$.

In the process of plant vegetation, protein and carotene content decreases, and fiber content increases. So, digestibility and the energy value reduce.

The study of the dynamics of the nutritional value of the botanical composition of pasture grasses has shown that Bromusinermis and Poapratensis in all phases of the growing season contain the most deficient nutrient, protein, in the feed balance more than other grains. Dactylisglomerata is rich with protein. Moreover, if we consider that it is drought-resistant, starts growing in the spring early and is well eaten by animals, it is possible to recommend creating artificial pastures. Poapratensis and Festucapratensis contain more nitrogen-free extractive substances than Bromusinermis and Dactylisglomerata. Among legumes, Melilotusalbusis the richest with protein. At the booting phase it contains by $0.7 \% \mathrm{~g}$ more than Trifolium.

Thus, legume grasses are richer with calcium than phosphorus. At the booting phaseTrifoliumrubenshas calcium 8.5 times as much as phosphorus, Melilotus alba has calcium 7.7 times as much as phosphorus.

When plants get old, the levels of protein and ash decrease. Due to the increase of the fiber content, nitrogen-free extractives and dry matter in general, the amount of gross energy is higher at the flowering phase.

Thus, due to the decrease of digestibility of organic matter of "old" plants, the amount of metabolizable energy in the dry matter of herbs at the flowering phase is less than at the early stages of vegetation. 
The data of chemical composition in dry basis of pasture grass, depending on the NDVI, are especially interesting.

Field or route geobotanical researches of key areas with the selection of plant cuts for the analysis of chemical composition and cameral ones - at the areas of cuts according to the UAV data -have been made foridentifyingtheconnectionbetweentheNDVIandchemicalcompositionofpasturegrass. These data are presentedin Table 2.

Chemical composition of grass in relation to NDVI

Table 2

\begin{tabular}{|l|c|c|c|}
\hline \multirow{2}{*}{ Indicator } & \multicolumn{3}{c|}{ NDVI } \\
\cline { 2 - 4 } & 0.33 & 0.54 & 0.68 \\
\hline Crude protein, \% & $10.92 \pm 0.03$ & $11.15 \pm 0.06$ & $16.99 \pm 0.10$ \\
\hline Total moisture, \% & $4.72 \pm 0.07$ & $4.05 \pm 0.06$ & $3.77 \pm 0.06$ \\
\hline Crude fiber, \% & $26.66 \pm 0.13$ & $23.36 \pm 0.22$ & $20.58 \pm 0.24$ \\
\hline Crude fat, \% & $2.65 \pm 0.09$ & $2.39 \pm 0.05$ & $2.88 \pm 0.03$ \\
\hline Crude ash, \% & $8.14 \pm 0.03$ & $8.59 \pm 0.04$ & $8.65 \pm 0.11$ \\
\hline Calcium, \% & $0.74 \pm 0.03$ & $1.02 \pm 0.02$ & $1.09 \pm 0.02$ \\
\hline Phosphorus, \% & $0.03 \pm 0.01$ & $0.05 \pm 0.01$ & $0.04 \pm 0.01$ \\
\hline Exchange energy for sheep, kcal per 100 g & $8.64 \pm 0.02$ & $8.98 \pm 0.03$ & $9.93 \pm 0.02$ \\
\hline
\end{tabular}

The correlation index of the results of monitoring the NDVI on the pastures of the Stavropol Territory in the Russian Federation with the results of the actual nutritional value of forage plants has been 0.75-0.85.

Such an important indicator as crude protein in pasture grass takes a significant place in the structure of feed. The sample of grass with the NDVI 0.68 contains crude protein by 6.08 absolute $\%$ more than grass with the NDVI 0.33 , and by 5.84 absolute $\%$ more than grass with the NDVI 0.54 . The metabolic energy of pasture feed with the NDVI 0.68 is higher than the metabolic energy of pasture feed with the NDVI 0.33 and the NDVI 0.54 by $14.9 \%$ and $10.6 \%$, respectively. The map of NDVI area is presented in Fig. 2.

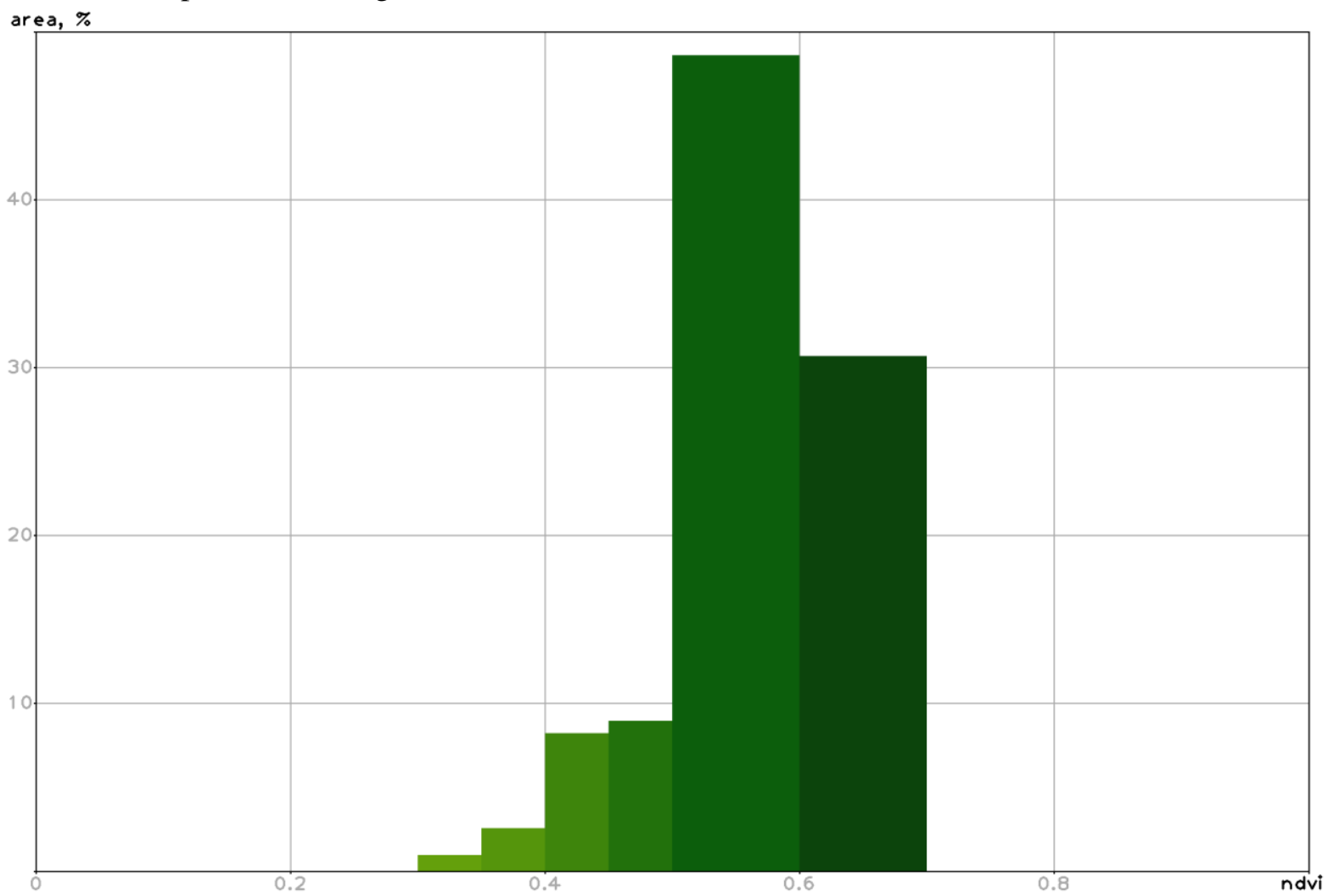

Fig. 2. Map of NDVI area 
Until recently, vitamins did not get attention in feeding farm animals, in particular, sheep. They seemed to be a secondary nutritional factor. At the present time they acquire some exceptional importance. Vitamin A and carotene play a very important role. It has been initially established that hypovitaminos is of vitamin A stops the growth of young animals and causes a decrease in the body weight. It has been established that vitamin A deficiency influences the regeneration and keratinization of epithelial cells, especially the skin, as well as the nervous system, sense organs, oral and intestinal cavities. In consequence, the productivity of animals decreases.

Thus, the content of carotene in pasture feed is extremely important. In our studies, an analysis of pasture grass has been carried out in the carotene content depending on the vegetation index (NDVI). The data obtained are presented in Figure 3.

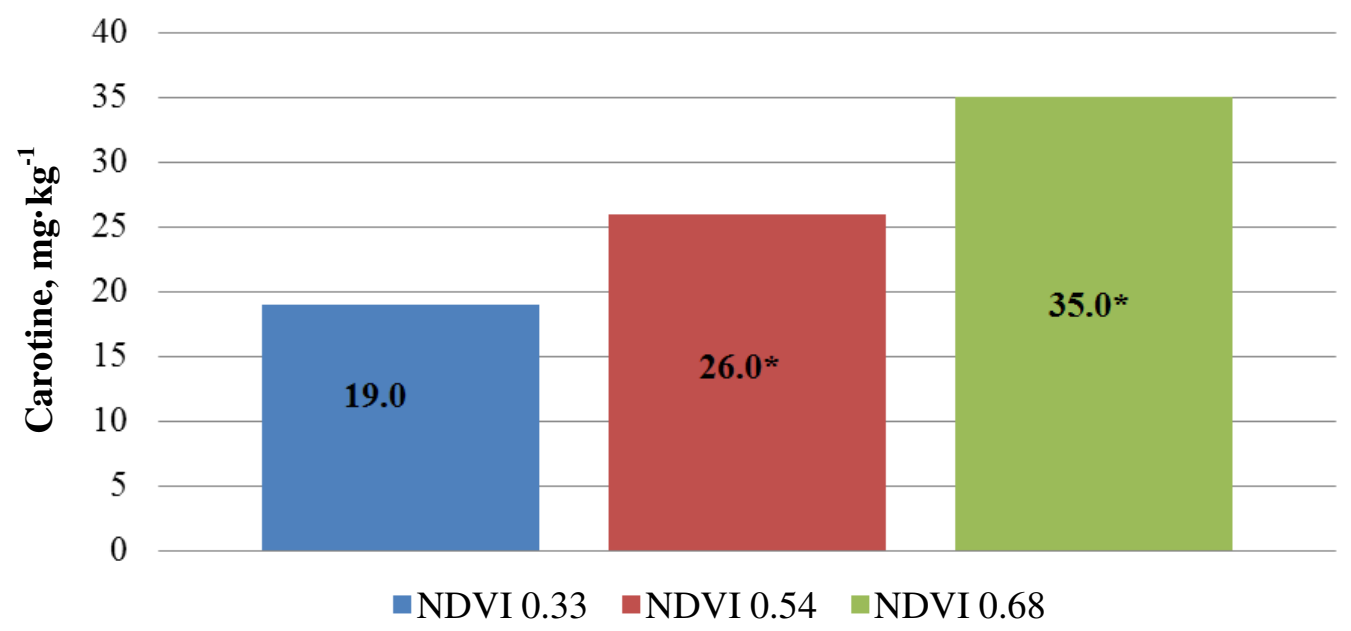

Fig. 3. Content of carotene depending on vegetative index, $* p<0.05$

The results have shown that the higher the NDVI, the more carotene is in plants. Pasture grass with the NDVI 0.68 contains carotene almost twice as much as grass with the NDVI 0.33 and by $34.6 \%$ more than grass with the NDVI 0.54. The correlation index is 0.98 .

The nutritional value of feed has a significant impact on the productive quality of rearing sheep. Live weight of the population in the groups is almost at the same level and makes23.57-23.81 kg as it is shown in Table 3.

Productive qualities of replacement young sheep of 4-6 months old, $M \pm m$

\begin{tabular}{|l|c|c|c|}
\hline \multirow{2}{*}{\multicolumn{1}{|c|}{ Indicator }} & \multicolumn{3}{c|}{ Group } \\
\cline { 2 - 4 } & I & II & III \\
\hline Live weight at the beginning, $\mathrm{kg}$ & $23.57 \pm 0.56$ & $23.81 \pm 0.48$ & $24.25 \pm 0.47$ \\
\hline Live weight at the end, kg & $34.29 \pm 1.12$ & $35.27 \pm 1.15$ & $36.24 \pm 1.13$ \\
\hline Average daily increase of live weight, $\mathrm{g}$ & $178.6 \pm 4.10^{*}$ & $191.0 \pm 3.80^{*}$ & $199.8 \pm 3.90^{*}$ \\
\hline
\end{tabular}

$$
* p<0.05
$$

The significant difference in the average daily increase of the live weight (10.6\% and $4.4 \%)$ has suggested that it is better to graze young sheep on pastures, the vegetative index of which is not lower than 0.60. It is advisable to use remote assessment methods to reduce the labor costs of assessing the state of pasture feed.

\section{Conclusions}

1. Whilegrowing Dzhalginskiy Merino sheep, it would be advisable to use remote methods for determining the vegetation index using unmanned aerial vehicles, for example, the AC-32-10 aircraft or the DJI s900 hexacopter, which are equipped with the Canon M10 camera and the software for calculating the NDVI.

2. While choosing a pasture area for growing replacement young sheep of Dzhalginskiy Merino breed, it would be advisable to use areas with the NDVI on the level 0.6. It will enable animals to 
actualize the genetically determined developmental potential on the level of average 187-195 $\mathrm{g}$ daily weight increase.

\section{Acknowledgements}

The work has beencarried out with the financial support of the Ministry of Science and Higher Education of Russia under Agreement No. 14.613.21.0081 dated November 22, 2017. Uniqueidentifierofworks: RFMEFI61317X0081.

\section{References}

[1] Fisher K. From the height of bird flight.New agriculture, 2015, №6, pp. 78-81.

[2] Martinelli F., Sca-lenghe R., Davino S., Panno S., Scuderi G., et al. Advanced methods of plant disease detection. A review.Agronomy for Sustainable Development, Springer Verlag/EDP Sciences/INRA, 2015, 35 (1), pp.1-25.

[3] Caturegli L., Corniglia M., Gaetani M., Grossi N., Magni S., Migliazzi M., et al. Unmanned Aerial Vehicle to Estimate Nitrogen Status of Turfgrasses, 2016,PLoS ONE 11(6): e0158268.doi:10.1371/jour-nal.pone.0158268.

[4] Landsat Data Continuity Mission. Press Kit, 2013 [online] [02.03.2019]. Available at: www.nasa.gov/pdf/723395main_LDCMpresskit2013-final.pdf.

[5] Антонов В. Н., Сладких Л. А. Мониторинг состояния посевов и прогнозирование урожайности яровой пшеницы по данным ДЗ3// Геоматика. 2009. № 4. С. 50-53. (Antonov V. N., Sladkikh L. A. Monitoring of the condition of crops and forecasting of spring wheat according to the Earth remote sensing. Geomatika, 2009, No. 4, pp. 50-53).(In Russian).

[6] Hatfield J., Gitelson A., Schepers J. et al. Walthall Application of Spectral Remote Sensing for Agronomic Decisions. Published in Agron. J., 2008, vol. 100, pp. 117-131.

[7] Al-Gaadi K.A., Hassaballa A.A., Tola E., Kayad A.G., Madugundu R., Alblewi B., et al. Prediction of Potato Crop Yield Using Precision Agriculture Techniques, 2016, PLoS ONE 11 (9): e0162219. doi: 10.1371 / journal.pone.0162219.

[8] Jiang Z., Huete A.R., Chen J., Chen Y., Li J., Yan G., Zhang X. Analysis of NDVI and scaled difference vegetation index retrievals of vegetation fraction. Remote Sensing of Environment, 2006, No.101, pp. 366-378.

[9] Караев В.В. Беспилотники в сельском хозяйстве // В сборнике: Научные труды Горского Государственного аграрного университета «Студенческая наука - агропромышленному комплексу» в 2-х частях. Владикавказ, 2016.C. 22-26 (Karaev V.V. Remote-piloted vehicle in agriculture. Proceedings of International conference "Scientific works of Gorskiy State Agrarian University "Student science is for the agro-industrial complex" in 2 parts, Vladikavkaz, 2016, pp. 22-26). (In Russian).

[10]Вертикова A.C. Аэрокосмический мониторинг опустынивания земель Саратовского Заволжья / А. С. Вертикова // В мире научных открытий. 2016. №9 (81). С.60-73 (Vertikova A.S. Aerospace monitoring of desertification of lands of the Saratov Trans-Volga Region.Intheworldofscientificdiscoveries, 2016, No. 9 (81), pp. 60-73). (In Russian).

[11]Бедарева О.М. Определение видового состава пустынно-пастбищной растительности с применением материалов крупномасштабной аэрофотосъёмки / О.М. Бедарева // Проблемы сохранения и рационального использования биоразнообразия Прикаспия и сопредельных регионов: материалы четвертой международной научной конференции. Элиста, 2006. С.1719 (Bedareva O.M.Determination of the species composition of desert-pasture vegetation using materials of large-scale aerial photography. ProceedingsofInternationalconference "Problems of saving and rational using of biodiversity in Pre-Caspian Region and neighboring areas", Elista, 2006, pp.17-19).(In Russian).

[12]Бедарева О.M. Технология инвентаризации пустынно-пастбищной растительности методами дистанционного зондирования/ О.М. Бедарева // Фундаментальные достижения в почвоведении, экологии, сельском хозяйстве на пути к инновациям: материалы всероссийской научно-практической конференции. М.: МГУ, 2008. С. 167-168 (Bedareva O.M.Technology of inventory of desert-pasture vegetation by remote sensing methods. Proceedings of Russian conference "Fundamental achievements of soil science, ecological 
science, agriculture on the way to innovations", Moscow, Moscow State University, 2008, pp. 167-168).(InRussian).

[13]Брыксин В.М., Евтюшкин А.В., Кочергин Г.А., Рычкова Н.В. Мониторинг зерновых культур на юге Западной Сибири по данным MODIS и ERS-2 // Материалы Международной научной конференции «Зондирование земных покровов радарами и радиометрами с синтезированной апертурой». Улан-Удэ, п. Энхалук., 24-29 июня 2013 г., c. 79-81 (Bryksin V.M., Evtyushkin A.V., Kochergin G.A., Rychkova N.V.MonitoringofgraincropsinthesouthofWesternSiberiaaccordingtoMODISandERS-

2.ProceedingsoftheInternationalScientificConference"Sensing ofthe Earth covers with synthetic aperture radars and radiometers", Ulan-Ude, villageEnhaluk., June 24-29, 2013, pp. 79-81). (In Russian).

[14] Crippen R.E. Calculating the Vegetation Index Faster. Remote Sensing of Environment, vol. 34, pp. 71-73. 